\title{
Formation of Design and Research Competencies in Future Teachers in the Framework of STEAM Education
}

\author{
https://doi.org/10.3991/ijet.v15i02.11537 \\ Tatyana I. Anisimova, Fairuza M. Sabirova, Olga V. Shatunova ( $\left.{ }^{-}\right)$ \\ Kazan Federal University, Elabuga, Russian Federation \\ ovshatunovaekpfu.ru
}

\begin{abstract}
In today's digital society and economy, professions associated with high technologies are becoming increasingly in demand: programmers, system engineers, IT specialists, biotechnologists, project leaders, etc. In this regard, school graduates should have not just good knowledge of school subjects, but also interdisciplinary knowledge, the formation of which is a long process, starting already in school, and cannot be achieved by using only traditional methods. One of these innovative technologies is STEAM education (Science, Technology, Engineering, Art, and Mathematics). To implement the concept of STEAM education, the system of pedagogical education is tasked with training the relevant personnel with the necessary competencies, among which the most relevant ones are meta-subject and design and research skills. In the authors' opinion, one of the possible innovations in the preparation of teachers for STEAM education is the inclusion of the "Robotics" discipline in the content of training of future teachers of physics, mathematics, technology, visual arts, and others. The authors conducted a survey among future teachers studying at the Faculty of Mathematics and Natural Sciences and the Engineering and Technology Faculty of the Yelabuga Institute of Kazan Federal University, which showed that the problem of preparing graduates of general education institutions for the challenges of the new time is more relevant than ever. Only $18 \%$ of respondents are aware of the STEM and STEAM education programs existing in the world and the country, $15 \%$ of the students surveyed believe that they are ready to implement project activities and only $10 \%$ of students believe that they are ready to lead project activities. These data indicate that not only the problem of teachers' readiness to implement new educational programs, but also the problem of preparing future teachers to implement practice-oriented educational activities based on the formation of design and research competencies is coming to the fore.
\end{abstract}

Keywords-STEM, STEAM, robotics, design and research skills, project method.

\section{Introduction}

The digital transformation of society, taking place today, entails radical changes not only in the economic sphere but also in the social sphere, including education. The 
disappearance of a number of professions and the emergence of new ones aggravates the problem of developing people's meta-subject skills, as well as the skills of selfeducation and self-development, which ensure good job opportunities and determine success in professional activities (Colucci-Gray et al., 2017).

Obviously, in these conditions, the search for innovative approaches to training for the digital society is necessary. In many advanced countries, such as Australia, Great Britain, Israel, Canada, China, Singapore, and the United States, the so-called STEAM education is being developed, the idea of which has become a continuation of the STEM education concept (Science, Technology, Engineering and Mathematics). For example, in the United States, STEM education is recognized by the National Research Council and the National Science Foundation (NSF) as the technological foundation of a developed society. The degree of training in the field of STEM is an indicator of a nation's ability to support its development (Frolov, 2010).

STEM education aims to ensure that children, creating various projects, can understand the practical application of the theoretical knowledge that they received in the lessons of mathematics, technology, and other natural science disciplines. Moreover, it is often stated that the knowledge in the field of mathematics, engineering and the natural sciences obtained at school is not enough. Therefore, it became necessary to include creative disciplines in STEM education, which can be designated by the term "Arts", which expands this area and enriches it with the creative component (STEAM) (Tarnoff, 2011; Sousa \& Pilecki, 2013). For example, the experience of Asian countries such as Singapore and China demonstrates to the world the benefits of STEAM education as compared to STEM education. The data from a survey conducted at the beginning of the 21 st century showed that parents in China believe that arts are particularly important for shaping the innovative skills of the younger generation. In China, the role of mathematics and computer science is estimated at 9\% (out of $100 \%$ of all sciences), the value of creative approaches for solving innovative problems is estimated at $45 \%$, the importance of entrepreneurial and business skills is recognized by $23 \%$, the value of knowledge of world cultures - by $18 \%$. All this suggests that STEAM education already exists in China, while STEM still prevails in the USA (Frolov, 2013).

The unity of science, technology and arts in education is also explained from a physiological point of view. The so-called "left" side of the brain is responsible for the logic: it helps to memorize the facts and derive logical conclusions. The "right" side of the brain is responsible for thinking through direct perception and provides creative, instinctive-intuitive thinking (Kurniawan et al., 2019). The work of both hemispheres is important: if one of them does not work, then it, like any muscle of the body, will become atrophied, unclaimed. Therefore, it is wrong to make a choice between technical and human sciences; they must be harmoniously combined in the content of education, which fully meets the needs of the economy of Industry 4.0. Members of the bipartisan commission for the development of STEAM education, created in 2013 in the US Congress, stated that "only activation of both hemispheres of the brain will teach people to think innovatively and creatively, which will be crucial for the growth of the economy in the 21 st century and the creation of highly efficient jobs". According to the head of the personnel service of the medical company 
Rally Health, Tom Perrault, especially in the near future, the IT business will be particularly in need of STEAM specialists, since robots are about to begin to cope with duties that require STEM education better than humans. However, the humanities (for example, psychology or art) are unlikely to master machines in the foreseeable future. The development of product design, its aesthetics and philosophy will help IT specialists in the near future to create new competitive solutions and therefore humanitarian disciplines will be needed here that teach students to understand human nature and think creatively (Perrault, 2016).

The idea of using the methods of diversified development in the field of education is not some kind of know-how. For example, there is the SEL concept, which implies the development of social and emotional skills in children, which are heavily relied upon in educating "people of the future". Or the method of phenomenon-based learning and teaching (PBL), similar to STEM in the sense that both methods try to combine different disciplines when studying or working on a topic (Estapa \& Tank, 2017). The mentioned PBL methodology and the STEM concept in many respects provide for the reinforcement of technical disciplines with humanitarian ones. Therefore, the logical step was an attempt to "legitimize" such an association, to connect the creative aspect of personal development to the purely technical concept of STEM. So there appeared systems that, along with science, technology, engineering and mathematics, included art - this is the concept of STEAM, music - STEMM, reading along with art - STREAM. The most widespread is the technique of STEAM, which is the most fullfledged one.

In general, if one evaluates the prospects of these two concepts - the "pure" STEM and STEM with a creative component, then the first one was more in demand at the end of the last century. At the same time, STEAM can adequately and effectively respond to the challenges of not only today but also the future. Here one can refer to the fact that a significant part of workflows is already amenable to automation, and in the future, as analysts predict, more and more professions will fall into the risk zone, disappearing one after another - they will be replaced by artificial intelligence. For the time being, among the few skills that in the foreseeable future will not resist the pressure of artificial intelligence, there are empathy and emotional intelligence.

Studies on the implementation of STEAM elements of education are conducted in many countries: USA, Australia, South Korea, Canada, Thailand, etc. The possibilities of including the element "Art" used in the abbreviation STEAM, as shown by the study of the experience in implementing STEAM education, are quite diverse, and expand as students go through the basic levels of education. The question of the specific ways and methods of combining STEAM disciplines into an integrated whole remains debatable. The following terms are proposed for this process: transdisciplinary, interdisciplinary, multi-disciplinary, cross-disciplinary, and arts-integration (Perignat \& Katz-Buonincontro, 2019).

For example, in kindergartens and elementary grades, such an area of physical knowledge as acoustics can serve as an element connecting STEM and STEAM. According to researchers, acoustics is ideal for STEAM, because it is closely related to one of the arts, music (Goates et al., 2017). The beneficial effect of music and musical rhythm on the study of mathematics is also proved by experimental studies (Hamilton 
et al., 2019). It is clear that this requires training of pedagogical personnel, and there is such an experience of cooperation (training) of the Acoustics Research Group at Brigham Young University (BYU) with primary school teachers who subsequently successfully integrated art into teaching activity (Goates et al., 2017). Work to increase interest in physical phenomena among younger students can be integrated into the STEAM education system (Sabirova \& Deryagin, 2018).

Researchers at Ghent University argue that by incorporating art into STEM programs, educational activities may become more attractive to a wider audience. As a model of such educational activities, they represent the international week of robotics and art for high school students (Wyffels et al., 2016).

Scholars from Finland (Thuneberg et al., 2017) point out the need to increase creativity in math education in school. They offer a mobile interactive mathematical exhibition "The Art of Mathematics".

In Australia, an educational program has been developed, according to which teachers include in STEM education programs for the study of the history and culture of Aboriginal and Torres Strait Islanders, the economic and cultural interdependence of Australia and Asia (Taylor, 2018).

In 2011, in Chicago, the Scientists for Tomorrow (SfT) initiative was supported. The SfT initiative is designed to use a STEAM-based curriculum and is a partnership between higher education institutions, out-of-school organizations and non-formal education providers. The initiative is implemented in all communities during the school year. In the framework of this initiative, young people in their spare time study various educational modules, such as Alternative Energy, Physics of Sound and Mathematics of Music, People and Plants, Robotics and Astronomy (2017). This initiative helped to increase the level of knowledge in the areas of interest and increase a positive attitude towards STEAM.

In 2015, the three-year project "ER4STEM" (Austria, Bulgaria, Greece, Malta, and the United Kingdom) was launched. Its aim is the creative and critical use of educational robotics to keep students interested in the science and technology industry. The goal of "ER4STEM" is to develop an open and conceptual framework that allows children to study various areas of educational robotics and STEAM (Ionkina, 2018). The project provides for the holding of the annual European Conference on Educational Robotics.

In Russia, this problem is also understood. In particular, Education Technological Support Centers are created, which partially solve the problem of attracting students to engineering and robotics. Business companies are actively involved in the implementation of projects for subject-oriented education of children and young people, which confirms the correctness of this strategy in education. Through the convergence of engineering, natural science and humanities, teachers create favorable conditions for the development of metacompetencies among students that they need for successful professional activity in the future.

In Russian STEAM centers, project laboratories are created for this purpose, combining science, technology, and art (Leading Universities, 2017).

The need for an interdisciplinary approach in STEAM education (inter-, trans- and cross-disciplinary learning), implemented with the cooperation of subject teachers, the 
use of creativity in the work of secondary school teachers to develop critical thinking of students, was convincingly substantiated by high schools in Australia, USA, Canada, and Singapore (Harris \& Bruin, 2018). The study showed that in establishing trusting relationships between teachers and students, favorable conditions are created for the development of the creative potential of both.

Some countries are conducting experiments on the use of interdisciplinary strategies for university and secondary school teachers. The results show that using STEAM technologies in the study of physical and mathematical disciplines by high school students and university students (Segura, 2017; Alajmi, 2019; Chanthala et al., 2018; Shatunova et al., 2019) improves academic performance and self-esteem, as well as develops creative abilities.

The experience of research in Korea in the field of STEAM education also shows that it is preferable to carry out physical research in connection with the humanities and arts (Paik et al., 2018; Moon \& Kang, 2015).

Thus, the implementation of STEAM education is feasible at all levels of education, ranging from pre-school to professional, often in close cooperation and cooperation of educational and extracurricular organizations.

CONCEPT OF TEACHING PEDAGOGICAL PERSONNEL FOR STEAM EDUCATION

Today in Russia for the implementation of the concept of STEAM education, the system of pedagogical education is tasked with training relevant personnel with the necessary competencies, among which the most popular ones are meta-subject and design and research skills. In the formation of these competencies, an important role is assigned to pedagogical universities. Currently, a graduate of a pedagogical university, apart from the ability to solve standard professional tasks in training, educating and developing the younger generation, should be ready to generate new ideas, implement them in projects, conduct research and put its results into practice (Korableva et al., 2019).

The problem of training is of concern to all countries in which robotics is gaining popularity. So, in particular, in 2000 in the USA, the Academy of Robotics at the Carnegie Mellon Institute (CMRA) was established. CMRA initially explored the motivational effects of robotics to attract schoolchildren to STEAM education, and then began to develop training programs for teachers in robotics (Flot et al., 2013, Liu et al., 2013).

In the authors' opinion, one of the possible innovations in the training of teachers for STEAM education at the master's level is their training in the framework of modules that combine disciplines and practices for each STEAM block: Science, Technology, Engineering, Art, and Mathematics.

The Science block should include such disciplines as Pedagogy, Psychology, Physics, Chemistry, Biology, etc. The Technology block should contain, for example, such disciplines as "Educational Robotics", "Digital Resource Utilization Technologies", "Distance Learning Technologies", etc. The disciplines of the Engineering block should be focused on developing undergraduates' design and research competencies, design and modeling skills required by an engineer. They may be such disciplines as "Fundamentals of Engineering Design". The Arts category, implemented in the ap- 
propriate module, involves creative learning activities in such subjects as "Design", "World Art Culture", "Art Pedagogy", possibly "Music", etc., and the Mathematics block should include math disciplines.

The authors believe that the key discipline in the content of training teachers for STEAM education should be "Educational Robotics". Educational robotics is suitable for all ages - from preschoolers to students of the vocational education system, as it implies theoretical training, technical creativity, and training during the game. Robotics in education includes interdisciplinary classes that integrate science, technology, engineering, art, and mathematics, based on the use of active teaching methods. The main purpose of this course is to develop students' design and research skills in the process of creating objects of robotics. During classes in robotics, students study the design and programming of robotic devices, measurement systems, etc., which creates the necessary basis for the further development of engineering and creative competencies. Coming to school, teachers trained in the field of STEAM education will be able to organize the process of learning the fundamentals of robotics, using knowledge from mathematics, physics, technology, biology, social studies, English and other subjects (Silk, 2011).

The inclusion of students in the work with special robotized construction kits, the solution of problems taken from life, requires the integrated use of knowledge from various sciences, communication in teams, the implementation of completed projects, design abilities, and the ability to present the result. Most often, one has to work on creating one's own robots from ready-made blocks of a special construction kit and writing programs for managing them.

In Russia, there is an educational and methodological center of innovative education (http://фгос-игра.рф). On its web pages, one can find a variety of materials for introducing elements of robotics into the secondary school educational process in the lessons of computer science, physics, mathematics, biology, as well as in extracurricular, including project and competitive, activities.

The experience of Russian educators using robotics in the educational process allows concluding that the following positive aspects can be distinguished:

- Awareness of a clear relationship of knowledge from different academic subjects, the development of creative thinking;

- Implementation of practice-oriented learning, engaging schoolchildren in research and project activities;

- Formation of the ability to bring the idea to its real embodiment, the final result;

- Development of students' communication skills and abilities to work in a team, sharing the results;

- Increasing students' motivation associated with the above aspects, the attractiveness of the environment created using active, game, problem-oriented, team learning techniques with elements of competition, as well as working with robotic construction kits, which interests and motivates students in itself (Sirenko, 2017).

Based on the foregoing, it can be concluded that the leading method of studying robotics should be the project method, which provides ample opportunities for the intellectual development of students and the formation of important skills: to set cog- 
nitive and practical tasks; analyze problem situations; design goals; develop and test hypotheses; plan the achievement of goals; evaluate decisions and make informed choices; work effectively in a group.

All practices envisaged by the STEAM teacher training curriculum must also be design-technological. Work on projects in the conditions of "creative spaces" will provide an opportunity to form and develop in each student the skills and competencies that are necessary for a person of the digital century: awareness of the achievement of the result of project activities; initiative creative independence; selfmanagement; communication and cooperation; integration and systems approach to problem solving (Savinova \& Shubnyakova, 2015; Khouna et al., 2019).

The validity of the authors' proposals is confirmed by the data of research conducted by scientists in different countries implementing the ideas of STEAM education. For example, Harris and de Bruin provide evidence that STEAM educational activities, based on collaboration between teachers and children in the classroom, contribute to the development of critical and creative thinking (Harris \& de Bruin, 2018). This, in turn, affects the increase in the level of interconnectedness and interdisciplinarity of education. Conradty and Bogner believe that students' creativity is a complex activity that is difficult to evaluate, but it also introduces new impulses into STEM education and leads to a better perception of science by adolescents (Conradty \& Bogner, 2018; Houda et al., 2019). Therefore, increasingly active efforts are being made to integrate traditional art (arts) into the transformation of STEM into STEAM.

However, many teachers are not yet ready to develop STEAM curricula. The study (Kim \& Lee, 2018) showed that high school teachers demonstrated a low level of proficiency in STEAM tools and did not express confidence in the need to restructure the curriculum. In contrast, primary school teachers wanted to improve their understanding of STEAM education through participation in learning. High school teachers expressed an acute need for educational programs that could be applied in the classroom, and wished to develop them through practical training. In the course of this study, it was confirmed that the demand for teacher training in STEAM is different, and it is necessary to approach this differentially.

\section{Methods}

In order to fulfill the task of the research - to determine the ways and means of forming future teachers' research competencies in the framework of STEAM education, first it is necessary to analyze the existing state of readiness to implement the elements of the STEAM concept in education, as well as to address issues related to the readiness for the formation of project-research competencies. To identify the readiness for the formation of project-research competencies of teachers of mathematics, physics and technology, in March-April 2019, a survey was conducted among future teachers studying at the Faculty of Mathematics and Natural Sciences and Engineering and Technology Faculty of the Yelabuga Institute of Kazan Federal University. Eighty students took part in the survey (male $-63.9 \%$; standard deviation -1.01 ; female $-36.1 \%), 65$ of whom were enrolled in the last and penultimate undergraduate 
courses, 15 people were enrolled in the first course. The average age of participants was 21 years old, men $-36(45 \%)$, women $-44(55 \%)$. To compare the survey results, a survey was also conducted among working teachers of mathematics and physics; the number of participants was 21 people, the average age was 48 years old, 14 women (66\%) and 7 men (33\%). All participants were informed about the purpose and content of the questionnaire, that the diagnostic results would be confidential, all points regarding the ethics of the study were agreed.

The questionnaire consisted of 8 questions, of which 4 - with a choice of one answer, 4 - one or several. The first question "Do you know the concept of STEM/STEAM education?" provided for one of three answers: "yes", "I have an idea", "no". The choice of one of the three answers suggested the following questions: "At what level do you think your creative abilities are formed?" (I can put forward a new idea, I can improve a ready-made idea and use it, I can use a ready-made idea); "At what level, in your opinion, are the skills of the project activity formed?" (ready for its implementation, I have an idea, I don't know it), "Are you ready to lead the project activities of students?" (Fully ready, I have partial submission, not ready). Among the questions with the choice of several answers were: "What component of the content of your training at the university, in your opinion, is not enough?"; "What other disciplines, in your opinion, should be included in the content of your training at the university?", "What skills of critical thinking do you have?", "What skills of creative thinking do you have?". The suggested answers are given in more detail in the next section of the article.

\section{Results}

The survey showed that only $18 \%$ of the respondents were familiar with the concepts of STEM/STEAM education, 33\% had an idea about them, and the remaining $49 \%$ did not know anything about them. To the question "What component of the content of your training at the university, in your opinion, is not enough?" $58 \%$ of respondents answered "art (creativity)", 40\% - "technology", 24\% - "engineering", $18 \%$ - "science", 9\% - "mathematics". Fifty percent of students believed that the discipline "Fundamentals of Project Activity" should be included in the content of their basic training, 33\% - "Psychology of Creativity", 23\% - "Art History". In addition, it was proposed to include in this list educational robotics, the basics of oratory, and modern IT technologies. When identifying the level of formation of creative abilities, it turned out that $34 \%$ of future teachers could put forward a new idea, $51 \%-$ improve a ready-made idea and use it, $15 \%$ - use a ready-made idea. Among the skills of critical thinking possessed by the respondents, the search for compromise solutions $(60 \%)$ and the willingness to correct their mistakes $(68 \%)$ were highlighted. Thirtyfive percent of respondents had other skills, such as willingness to plan, flexibility, perseverance, the reflection of their own thinking process. When revealing the possession of creative thinking skills, it turned out that $43 \%$ of respondents were able to see the problem, could be attentive and visionary, $43 \%$ had a solid perception of the situation, $38 \%$ had the skills of an objective assessment of the situation, $36 \%$ had the flex- 
ibility of thinking, $35 \%$ - the ability to transfer a solution of one situation to another, $31 \%$ - ease in creating new ideas, $28 \%$ - the ability to generalize, to see the general trend in isolated aspects of information. Only $15 \%$ of the students surveyed believed that they were ready for the implementation of project activities, $71 \%$ had an idea about this, and $14 \%$ did not have the skills of project activities. Accordingly, $10 \%$ of students believed that they were ready to lead project activities, $65 \%$ had a partial understanding of this, and $25 \%$ were not ready. These data indicate that not only the problem of teachers' readiness to implement new educational programs, but also the problem of preparing future teachers to implement practice-oriented project activities comes to the forefront based on the formation of project-research competencies in the framework of STEAM education.

It should be noted that the results of the survey conducted among teachers, in general, correlated in percentage terms with the results of the survey among students. The only difference was that $67 \%$ of teachers said they were ready to carry out project activities (against $15 \%$ of students), and $71 \%$ said they were ready to fully manage the project activities of schoolchildren (against $10 \%$ of students). The transition of the education system in Russia to the federal state educational standards of a new generation provides for the active use of the project method in the educational process.

\section{Discussion}

The results of the current study are confirmed by studies of other scientists from different countries. In the context of globalization and increasing complexity, universities must show great ingenuity in order to adapt to changing conditions. Therefore, projects are one of the important tools for success (Cerezo-Narváez et al., 2019; Shkunova \& Pleshanov, 2017; Bozhkova et al., 2019).

A survey of university students conducted by researchers (Kudinova \& Skulmovskaya, 2018) to identify graduates' readiness for project activities and solving professional problems showed that for $34.7 \%$ of the surveyed students, the implementation of project activities during the training period contributed to a better understanding of the specifics of the future profession. Project activities for the graduates who participated in the survey became "significant, allowing them to feel their contribution" $-52 \%$, "interesting, exciting" - 53\%, "complex, requiring additional knowledge" $-41 \%$ (the sum of answers is more than $100 \%$, since there was multiple choice). The absence of negative answers generally indicates the readiness of graduates for project activities and for the fulfillment of professional tasks. So, according to the results of the study, the following conclusions can be formulated. The main advantages of the project activities of students at the university are their research and interdisciplinary character, proximity to the specifics of the future professional activity.

Researchers from Kozma Minin Nizhny Novgorod State Pedagogical University analyzed the willingness of students of the 1st-3rd years of study to complete projects that comprise research, analytical, performing, communicative and reflective activities (Shkunova \& Pleshanov, 2017). It is noted that the readiness of students for pro- 
ject activities increased with each course with the acquisition of new knowledge, skills and experience of project activities. In particular, the work notes that approximately the same number of first-year respondents positively identified their analytical skills. At the same time, they were reluctant to take part in various projects and competitions, because they did not see the point in this type of activity and were satisfied with the results, which provided them with a minimum rating score. Third-year students could already adequately assess their level of competence in the implementation of the project. The authors note that the readiness to reflect in the 3rd-year students increased almost twice as compared to the first year. This indicator indicates that students can analyze where, at what stage they had malfunctions, what are the advantages and disadvantages of the projects.

Researchers at the College of Engineering and the Faculty of Fundamental Sciences of the University Politécnico Grancolombiano described the approach, development and results of research projects used in industrial engineering programs, systems engineering and systems management technology. It is shown that the integration of educational, methodological and evaluation strategies allows transforming not only the classroom practices and curricula, but also the management processes of educational, teaching and research processes. Thus, the professional development of teachers, pedagogical management and the research potential of the university are strengthened (Pizarro, 2018).

\section{Conclusion}

The task of pedagogical education is to prepare students to become modern and effective teachers, capable of introducing innovations into the educational process, and leading the design and research activities of schoolchildren. To do this, students should be not only methodically prepared but also socially responsible and have the opportunity to be constantly innovative.

The results of the experimental work confirmed that support and active implementation of STEAM education should be carried out through targeted development programs, which, in turn, should include the active involvement of students and their mentors in design and research activities.

At the same time, first of all, during the preparation of future teachers for professional activities, it is necessary to work on the formation of cognitive, intrapersonal and interpersonal skills, but for this it is necessary to conduct active explanatory work on global educational trends, among which first STEM, and subsequently STEAM come to the forefront.

The implementation of the concept of STEAM education allows bringing to a new level the component "Art" having an important potential for the formation of future teachers' project-research competencies, such as introduction of additional disciplines to educational programs, development of critical thinking skills and creative, project activities, which are to be formed in the process of preparing future teachers. All this can be implemented in robotics classes, aimed at developing creative and communicative competencies, engineering and design and research skills. 
The analysis of the current state of future teachers' readiness to implement the elements of the STEAM concept in their professional activities, to develop design and research competencies in students showed that this problem is relevant and is of interest for the world academic community; not all aspects of its solution have been considered, so it requires further study.

\section{$6 \quad$ References}

[1] Aleksankov, A. M. (2017). The Fourth industrial revolution and modernization of education: international experience. Strategic priorities, 1(13), 53-69.

[2] Aletdinova, A.A. (2017). From the development of cognitive abilities of workers to the formation of network competencies in the digital economy. Trends in the economy and industry in the context of digitalization. St. Petersburg: publishing house of the Polytechnic University, 230-246.

[3] Alajmi, M. A. (2019). The impact of E-portfolio use on the development of professional standards and life skills of students in the Faculty of Education at Princess NouraBint Abdul Rahman University, Entrepreneurship and Sustainability Issues 6(4) 1714-1735. http:// doi.org/10.9770/jesi.2019.6.4(12)

[4] Bozhkova, G. N., Shastina, E. M., Kalimullina, O. V., \& Shatunova, O. V. (2019). Study of literary images of gifted characters in optional activities as a means to develop capable and talented youth. Space and Culture, India, 7(1), 264-273. https://doi.org/10.20896/saci. v7i1.463

[5] Caplan, M. (2017). Scientists for tomorrow - A self-sustained initiative to promote STEM in out-of-school time frameworks in under-served community-based organizations: Evaluation and lessons learned (Conference Paper). ASEE Annual Conference and Exposition, Conference Proceedings Volume 2017 - June, 24 June 2017124th ASEE Annual Conference and Exposition; Columbus; United States; 25 June 2017 through 28 June 2017; Code 129594. https://doi.org/10.18260/1-2--28812

[6] Chanthala, Ch., Santiboon, T., Ponkham, K. (2018). Instructional designing the STEM education model for fostering creative thinking abilities in physics laboratory environment classes. AIP Conference Proceedings. Vol. 1923, 030010-1-030010-12. https://doi.org/10. $1063 / 1.5019501$

[7] Colucci-Gray, L., Trowsdale, J., Cooke, C. F., Davies, R., Burnard, P., \& Gray, D. S. (2017). Reviewing the potential and challenges of developing STEAM education through creative pedagogies for 21 st learning: How can school curricula be broadened towards a more responsive, dynamic, and inclusive form of education? British Educational Research Association. www.steamresearch.wordpress.com

[8] Conradty C., Bogner F. X. (2018). From STEM to STEAM: How to Monitor Creativity. Creativity Research Journal. No. 30 (3), 233-240. https://doi.org/10.1080/10400419.2018. $\underline{1488195}$

[9] Estapa, A.T., Tank, K.M. (2017). Supporting integrated STEM in the elementary classroom: a professional development approach centered on an engineering design challenge. International Journal of STEM Education. Vol. 4, Issue 1, https://doi.org/10.1186/s40594017-0058-3.

[10] Flot, J., Shoop, R. (2013). Robotics Research at Carnegie Mellon Robotics Institute. URL: https://www.cmu.edu/roboticsacademy/PDFs/Research/WhyRoboticsTEEAP_2013.pdf

[11] Formation of digital economy and industry: new challenges (2018). St. Petersburg: publishing house of the Polytechnic University, 660 p. 
[12] Frolov, A.V. (2010). The Role of STEM education in the "new economy" of the USA. Questions of the new economy. 4 (16), 80-90.

[13] Goates, C.B., Whiting. J.K., Berardi, M.L., Gee, K.L., Neilsen, T.B. (2017). The sound of STEAM: Acoustics as the bridge between the arts and STEM. Proceedings of Meetings on Acoustics. Vol. 26, Is. 1, pp. 025002-1-025002-9. https://doi.org/10.1121/2.0000475

[14] Gratchev, I., Jeng, D.-S. (2018). Introducing a project-based assignment in a traditionally taught engineering course. European Journal of Engineering Education. Vol. 43, Issue 5, 788-799. https://doi.org/10.1080/03043797.2018.1441264

[15] Hamilton, T.J., Doai, J., Milne, A., (...), Goldwater, M., Cohn, R. (2019). Teaching Mathematics with Music: A Pilot Study. Proceedings of 2018 IEEE International Conference on Teaching, Assessment, and Learning for Engineering, TALE 2018, 8615262, 927-931. https://doi.org/10.1109/tale.2018.8615262

[16] Harris, A., de Bruin, L.R. (2018). Secondary school creativity, teacher practice and STEAM education: An international study. Journal of Educational Change. Vol. 19, Issue 2, 153-179. https://doi.org/10.1007/s10833-017-9311-2

[17] Houda, S., Naila, A., \& Samir, B. (2019). Knowledge management and reuse in virtual learning communities. International Journal of Emerging Technologies in Learning, 14(16), 23-39. https://doi.org/10.3991/ijet.v14i16.10588

[18] Ionkina N.A. (2018). Features of domestic and foreign experience in training teachers to teach robotics. RUDN Journal of Informatization in Education, 15 (1), 114-121. https://doi. org/10.22363/2312-8631-2018-15-1-114-121

[19] Khouna, J., Ajana, L., Rhazal, A., \& El Mokri, A. (2019). Are educational games engaging and motivating moroccan students to learn physics? an experimental study. International Journal of Emerging Technologies in Learning, 14(16), 66-82. https://doi.org/10.3991/ijet. v14i16.10641

[20] Korableva, O., Durand, T., Kalimullina, O., \& Stepanova, I. (2019). Studying user satisfaction with the MOOC platform interfaces using the example of coursera and open education platforms. Paper presented at the ACM International Conference Proceeding Series, 26-30. https://doi.org/10.1145/3322134.3322139

[21] Kim, S.-W., Lee, Y. (2018). An investigation of teachers' perception on STEAM education teachers' training program according to school level. Indian Journal of Public Health Research and Development, 9(9), 664-672. https://doi.org/10.5958/0976-5506.2018.01076. $\underline{8}$

[22] Kudinova OS, Skulmovskaya L.G. (2018). Project activities at the university as the basis of innovation. Modern problems of science and education. No.4 [Proyektnaya deyatel'nost' v vuze kak osnova innovatsiy. Sovremennyye problemy nauki i obrazovaniya. № 4] URL: http://www.science-education.ru/ru/article/view?id=27928

[23] Kurniawan, B., Idris, Purnomo, A., Wiradimadja, A., \& Sukamto. (2019). Using broadcasting learning design to enhance student's experiential skill. International Journal of Emerging Technologies in Learning, 14(16), 172-180. https://doi.org/10.3991/ijet.v14i16. $\underline{10652}$

[24] Leading Universities have joined forces to create an innovative educational platform "STEAM Academy 2030" URL: https://pikabu.ru/story/vedushchie_vuzyi_obedinili_ usiliya_po_sozdaniyu_innovatsionnoy_obrazovatelnoy_ploshchadki_steam_akademii_203 0_4987830

[25] Liu, A., Newsom, J., Schunn, C., Shoop, R. (2013). Students Learn Programming Faster Through Robotic Simulation. URL: https://www.cmu.edu/roboticsacademy/PDFs/Re search/LearnProgrammingFasterThroughSimulation.pdf 
[26] Maeda, J. (2012). STEM to STEAM: Art in K-12 is key to building a strong economy. Edutopia: What works in education. URL: http://www.edutopia.org/blog/stem-to-steamstrengthenseconomy-john-maeda.

[27] Mallinson, C. (2018). Technology-Enhanced Project-Based Learning: A Platform for Graduate Student Research and Outreach on Campus and in the Community. Journal of English Linguistics. Vol. 46, Issue 3, 229-245. https://doi.org/10.1177/0075424218783447

[28] Moon, S., Kang, K. (2015). Trend of STEAM education-related domestic studies focusing on physics-related studies. New Physics: Sae Mulli, Vol. 65, No. 12, 1199-1208. https:// doi.org/10.3938/npsm.65.1199

[29] Paik S.-H. Kim, S.-W., Lee, Y. (2018). A study on teachers practices of STEAM education in Korea. International Journal of Pure and Applied Mathematics. Vol. 118, Issue Special Issue 19B, 2339-2365.

[30] Perignat, E., Katz-Buonincontro, J. (2019). STEAM in practice and research: An integrative literature review. Thinking Skills and Creativity, Vol. 31, 31-43. https://doi.org/10.10 $\underline{16 / j . t s c .2018 .10 .002}$

[31] Perrault, T. (2016). Digital Companies Need More Liberal Arts Majors Harvard business review. URL: https://hbr.org/2016/01/digital-companies-need-more-liberal-arts-majors

[32] Pizarro, N.A.B. (2018). Using Research projects in the classroom to improve Engineering education Volume 2018-October, 4 March 2019, 48th Frontiers in Education Conference, FIE; San Jose; United States; 3-6 October 2018. URL: https://ieeexplore.ieee.org/ document/8659057. https://doi.org/10.1109/fie.2018.8659057

[33] Sabirova, F.M, Deryagin, A.V. (2018). The creation of junior schoolchildren's interest in the experimental study of physical phenomena using the elements of the technology of problem-based. International Journal of Engineering \& Technology. Vol. 7 (2.13), 150154. https://doi.org/10.14419/ijet.v7i2.13.11631

[34] Savinova, S., Shubnyakova, N.D. (2015). Project activity in professional training of bachelors-managers. Innovative projects and programs in education. No. 5, 46-52.

[35] Shatunova O., Anisimova T., Sabirova F., Kalimullina O. (2019) STEAM as an Innovative Educational Technology. Journal of Social Studies Education Research. Vol. 10 (2), 131144.

[36] Shkunova, A.A., Pleshanov, K.A. (2017). The organization of the project activities of university students: The results of the scientific research and development prospects. Vestnik of Minin University. No. 4, 4. https://doi.org/10.26795/2307-1281-2017-4-4

[37] Silk, E.M. (2011). Resources for learning ROBOTS: environments and framings connecting math in robotics. URL: http://www.education.rec.ri.cmu.edu/content/educators/ research/files/SilkEliM2011.pdf.

[38] Sirenko S., N. (2017). Educational robotics as a necessary element of training specialists for a new technological structure. Zh. Byelorussian State University. Journalism. Pedagogy. 2017. No. 1. P. 106-112. [Obrazovatel'naya robototekhnika kak neobkhodimyy element podgotovki spetsialistov dlya novogo tekhnologicheskogo uklada // Zhurn. Belorus. gos. un-ta. Zhurnalistika. Pedagogika. 2017. № 1. S. 106-112]

[39] Sebastianelli, R. (2018). Multiple student learning objectives in basic business statistics: Strategies, assessment, and recommendations. Journal of Education for Business. Vol. 93, Issue 7, 340-351. https://doi.org/10.1080/08832323.2018.1493421

[40] Segura, W.A. (2017). The use of STEAM in higher education for high school teachers. WMSCI 2017 - 21st World Multi-Conference on Systemics, Cybernetics and Informatics, Proceedings. Vol. 1, 308-312.

[41] Sousa, D.A., \& Pilecki, T. (2013). From STEM to STEAM: Using brain-compatible strategies to integrate the arts. Thousand Oaks: Corwin Press. 280 p. 
[42] Tarnoff J. (2011). STEM to STEAM. Recognizing the Value of Creative Skills in the Competitive. Huffpost. May 25, 2011. URL: http://www.huffingtonpost.com/johntarnoff/stem-to-steam-recognizing_b_756519.html

[43] Taylor, P.Ch. (2018). Enriching STEM with the arts to better prepare 21 st century citizens. AIP Conference Proceedings. Vol. 1923, 020002-1-020002-5. https://doi.org/10.1063/1.50 19491

[44] Thuneberg, H., Salmi, H., Fenyvesi, K. (2017). Hands-On Math and Art Exhibition Promoting Science Attitudes and Educational Plans. Education Research International, Vol. 2017, 1-13. https://doi.org/10.1155/2017/9132791

[45] Wyffels, F., Van de Steene, W., Roets, J., Ciocci, M., Carbajal, J. (2016). Building ArtBots to Attract Students into STEM Learning. CoRR abs/1608.03405.

[46] Frolov, A.V. Reform of the US Innovation System: From STEM to STEAM Education. Alma mater. No 1, 101-105. [Frolov, A. V. Reforma innovatsionnoy sistemy SSHA: ot STEM k STEAM-obrazovaniyu. Alma mater. № 1. 101-105]

\section{Authors}

Anisimova Tatyana Ivanovna, is a $\mathrm{PhD}$ in pedagogics. She is the head of the Department of mathematics and applied Informatics. She is an associate Professor at Kazan Federal University, Elabuga Institute, Elabuga, Russian Federation.

Sabirova Fairuza Musovna, $\mathrm{PhD}$ in physics and mathematics. She is head of the Department of physics. She is an associate Professor at Kazan Federal University, Elabuga Institute, Elabuga, Russian Federation.

Shatunova Olga Vasilyevna is a PhD in pedagogics. She is head of the Department of pedagogy. She is an associate Professor at Kazan Federal University, Elabuga Institute, Elabuga, Russian Federation.

Article submitted 2019-08-18. Resubmitted 2019-10-08. Final acceptance 2019-10-10. Final version published as submitted by the authors. 